\title{
Different perceptions of adaptation to climate change: a mental model approach applied to the evidence from expert interviews
}

\author{
Ilona Otto-Banaszak • Piotr Matczak • \\ Justus Wesseler $\cdot$ Frank Wechsung
}

Received: 9 February 2010/Accepted: 2 August 2010/Published online: 1 September 2010

(C) The Author(s) 2010. This article is published with open access at Springerlink.com

\begin{abstract}
We argue that differences in the perception and governance of adaptation to climate change and extreme weather events are related to sets of beliefs and concepts through which people understand the environment and which are used to solve the problems they face (mental models). Using data gathered in 31 in-depth interviews with adaptation experts in Europe, we identify five basic stakeholder groups whose divergent aims and logic can be related to different mental models they use: advocacy groups, administration, politicians, researchers, and media and the public. Each of these groups uses specific interpretations of climate change and specifies how to deal with climate change impacts. We suggest that a deeper understanding and follow-up of the identified mental models might be useful for the design of any stakeholder involvement in future climate impact research processes. It might also foster consensus building about adequate adaptation measures against climate threats in a society.
\end{abstract}

Keywords Mental models - Adaptation to climate change $\cdot$ Uncertainties

I. Otto-Banaszak $(\square) \cdot$ F. Wechsung

Potsdam Institute for Climate Impact Research,

Potsdam, Germany

e-mail: banaszak@pik-potsdam.de

P. Matczak

Institute for Agricultural and Forest Environment,

Polish Academy of Sciences, Poznan, Poland

J. Wesseler

Environmental Economics and Natural Resources Group,

Wageningen University, Wageningen, The Netherlands

\section{Introduction}

Growing losses caused by extreme weather events and predictions of increasing frequency of extreme events in the future have brought adaptation to climate change into the center of both the scientific and political agendas. Climate change poses challenges in terms of availability of financial resources, technology, and knowledge. Along with these needs, adaptation practices also face difficulties connected with the perception of risks and adaptation. Some studies have focused on the perception of climate change risks (Lorenzoni and Pidgeon 2006); however, there is little known about perception of climate change adaptation among stakeholders (Klein et al. 2007; McEvoy et al. 2006, McEvoy et al. in press).

The objective of this article is to explore the differences in the perception of adaptation to climate change among representatives of different stakeholder groups. We refer to the notion of mental models as being internal mental constructions interpreting and structuring the environment (Denzau and North 1994). In this article, we explore similarities and differences in prescriptions on how to adapt and how to govern adaptation across major groups of stakeholders involved in the development of adaptation policy. The paper qualitatively analyzes in-depth interviews recorded with 31 European experts in the area of adaptation policy to extreme weather events such as floods, heat waves, and droughts. The experts were selected to represent three groups: scientists, policy makers, and practitioners, in sectors such as agriculture, urban planning, and tourism.

The results suggest that although promising adaptation measures exist, they are often not implemented due to differences in stakeholders' mental models and different perceptions of how to adapt. The administrations 
responsible for adaptation tend to stick to the traditionally used engineering approach and believe in structural measures. Scientists tend to view the challenges of climate change in terms of the overall adaptation of society or different sectors. Policy makers and practitioners think and operate more in terms of costs, benefits, development, and wealth.

Our study also reports geographical differences in adaptation policies. Taenzler et al. (2008) argue that the ability of societies to deal with severe natural disasters depends on existing political, economic, and social conditions. Our results support the findings of Vari et al. (2003) who claim that in Eastern European societies, shared mental models that assume solidarity of taxpayers and responsibility of the state hinder the development of autonomous and private adaptation based for example on insurance instruments.

The article is organized as follows. Section 2 reviews the relevant literature and explores rich but complex and diversified theory behind the concepts of different perceptions and mental models, linking it with research on climate change and adaptation. Section 3 explains the research methodology. Section 4 presents the results of the empirical investigation structured according to the three main topics identified in Sect. 2: (i) the interviewed experts' different perceptions of adaptation, (ii) the reported array of mental models in use, and (iii) shared mental models identified in the interview groups. Section 5 provides a brief discussion of the research finding and relates them to adaptation policy. Section 6 summarizes and concludes the research.

\section{Literature review and theoretical considerations}

Different perceptions of adaptation to climate change

Several authors stress that perceptions about the environment and natural resources differ for individuals since their perceived world is subjectively constructed and is influenced by previous experience, type of education, and other socio-economic characteristics (Sudarmadi et al. 2001; Filip et al. 1983: 348; Feijoo and Momo 1991: 163). Irwin (1995) shows that different kinds of knowledge exist in the sphere of nature protection. Local and traditional knowledge is considered to be a supplement to abstract scientific expertise. Jennings (2009) presents a case of flood disaster management in Britain, where public participation reveals the coping capabilities of local communities. Excluding local knowledge and reducing flood disaster management to technical solutions usually leads to frustration and distrust. O'Brien (2009) notes a variety of worldviews in the context of climate change. She argues that both traditional values, connected with survival and satisfying the basic needs, and so-called post-materialistic (postmodern) values are involved in adaptation to climate change. Thus, adaptation is complicated by the need to address a spectrum of worldviews. O'Brien argues that the minimum task in adaptation is to identify the standpoint of each stakeholder. The importance of social values is acknowledged through adaptation to heat waves (Wolf et al. 2009). Perception of heat waves and an individual's assessment of coping with heat were revealed as crucial factors in decreasing mortality. Similarly, Tàbara and Ilhan (2008) show that changes in water policies in Spain were driven by a coalition of sensitive agents, mostly from academia, NGOs, and local constituencies, who managed to articulate new identities and develop new values.

Papadozomenou and Zikos (2009) compare perceptions of water scarcity in two samples of urban and rural stakeholders in Cyprus. The authors reveal that although both groups were aware that dramatic water problems are likely to intensify in the future, their perceptions of the nature of the problem and possible solutions were different. The urban sample held "technocratic" perspectives supporting technical measures such as the establishment of desalinization plants and installation of water saving technologies for dealing with extreme water shortages. On the other hand, the rural sample had a more holistic approach and believed that only environmental education and awareness campaigns can reduce water consumption. Papasozomenou and Zikos attribute the distinction between environmental perceptions of the two groups to the settings in which members of each group live (Papadozomenou and Zikos 2009: 756-757).

Mental models: the choice of appropriate means to defined ends

Sterman (2008), analyzing risk communication on climate change, draws attention to the role of different mental models which cause certain public beliefs to be difficult to change and pose significant obstacles for mitigation policy. These mental models sometimes violate fundamental physical principles. They refer to mental images of the world, composed of structural patterns of selected concepts and relationships representing the real system (Forrester 1971: 112). Mental models can be defined as preexisting mental constructs through which people decipher information and understand the environment, and which they use to solve the problems they face (Denzau and North 1994: 4). They provide a heuristic function by allowing information about situations, objects, and environments to be classified and retrieved in terms of their most important features (Cannon-Bowers et al. 1993: 226). Both the abilities of the individuals and the complexity of the problems 
play a role in mentally organizing the world (North 1990: 20). Mental models are shared by communication, resulting in the creation of institutions ${ }^{1}$ in a co-evolutionary process. Mental models and institutions help to reduce uncertainties in decision-making by structuring expectations about behavior of other individuals and the environment (Denzau and North 1994: 7-8).

Rouse and Morris (1986) summarize themes taken up by authors discussing the concept of mental models. They conclude that mental models help to describe, explain, and predict system behavior. However, mental models are more than simple mental images. They are flexible and manipulable, enabling individuals system states to be predicted through mental manipulation of model parameters. Thus, mental models are used as a basis for action (Senge 1990). Importantly, these mental representations of the environment that aid our understanding of the current and future states of the world are typically incomplete. Gaps or errors in mental models become apparent when interactions with the world lead to unexpected events (e.g., Besnard et al. 2004).

This typically leads to a correction of the mental model in use. However, sometimes the information feedback from choices is insufficient to enable adjustments of competing interpretations of the reality. Thus, multiple ways of addressing a particular problem might remain, some being, more effective in solving the problem than others (Denzau and North 1994: 4).

Forrester (1991) discusses a case where incomplete mental models used in policy-making resulted in such an intervention having an adverse effect. In the 1960s in the United States, it appeared natural that high unemployment and deteriorating housing could be combated by government intervention to build low-cost housing. However, low-cost housing programs appeared to be a social trap. They occupied land that could instead be used for jobcreating businesses, attracting people seeking work, and so generated a powerful double force for creating unemployment (Forrester 1991: 19).

Several authors discuss the importance of feedback for learning and a correction of mental models in use (Schoell and Binder 2009; Pahl-Wostl and Hare 2004; Schulser et al. 2003). Feedback delays and the fact that it is difficult to observe the connection between a particular action and its effect hinder learning and potential correction of inadequate interpretations of the environment (Denzau and North 1994: 7-8). We argue that climate change challenges mental models in use since it increases complexity and uncertainty. Increased complexity makes it more difficult to observe and to understand feedbacks. In dealing with

\footnotetext{
${ }^{1}$ Following North (1990: 3), institutions are understood as providing formal and informal rules that order interpersonal relationships.
}

climate-related stressors, feedbacks are often delayed or not transparent.

\section{Shared mental models}

Denzau and North (1994: 4) put forward that ideas and the way they are communicated among people are crucial in forming theories which enable people to deal at an individual level with problems that are characterized by large uncertainty. In situations of uncertainty, individuals interpret the environment in a way which reflects their learning. Individuals with common cultural backgrounds and experience share convergent mental models, ideologies, and patterns of behavior. Individuals with different learning experience will use different models to interpret the environment (Denzau and North 1994: 3-4).

Thus, although each individual possesses a unique mental model, some aspects are shared with others having similar experience or education. For an agent facing strong uncertainty, learning directly from the external environment and improving his/her mental models is slow. The process can be accelerated if there is some indirect learning in a form of artifactual models already created by others; that is if the agent already possesses some prior knowledge and a set of prior beliefs about possible outcomes of an action. Sharing mental models increases intellectual understanding. Such an intellectual understanding, with a set of concepts and language associated with it, eases communication. Moreover, the reception of a message and its interpretation are strongly influenced by experience and beliefs we already have about the world. If both the information sender and the information receiver have common features in their mental models, they are more likely to encode and decode their internal ideas into a shared language and are more likely to communicate effectively (Denzau and North 1994: 17-18, 20).

In addition, Vatn (2005) proposes that deciding which action is the most efficient is not only a technical issue but depends on the type of values decision-makers want to protect. In some situations, a market logic is applied when making environmental choices by societies; in other situations, norms of reciprocity and fairness are crucial for managing natural resources (Vatn 2005: 126, 128, 136).

In the context of our research, we might thus expect that interpretations of environmental changes and prescriptions of how to adapt to the changes will vary across societal groups that have different experience and education. Unclear feedback and feedback delays are expected to strengthen this variance and boundaries between groups. Following Vatn (2005), prescriptions of how to adapt might also vary between societies, and they will specifically reflect the societies' norms and values. 


\section{Organization of the expert interviews}

We carried out 31 interviews with experts between March 2007 and March 2009. The experts came from universities and other public and private research institutes, non-governmental organizations, private companies, and governmental and administrative organizations. The interviewees' expertise was related to adaptation to extreme weather events in European adaptation hot-spot areas, that is mainly Southern and Eastern Europe. These regions are particularly exposed due to changing precipitation extremes and the level of damages measured as a share of GDP (EEA 2007; Mechler et al. in press).

The notion of "experts" in research methodology refers to persons responsible for development, implementation or control of solutions, strategies or policies. Experts usually have a privileged access to information about groups of persons or decision processes and have a high level of aggregated and specific knowledge that is otherwise difficult to access. Expert interviews are usually recommended as a technique of data gathering in research fields that are new (Meuser and Nagel 1991). Research on adaptation to climate change is relatively new for both research and policy communities (Klein et al. 2007; McEvoy et al. 2006). Expert interviews were used to explore and to understand the main problems in adaptation research.

The experts were selected using the so-called snowball method. At the beginning, the researchers participating in the project "Adaptation and Mitigation Strategies Supporting European Climate Policy" (ADAM) were asked to recommend the first interviewees. Further on, each interviewee was asked to recommend further experts with whom we could talk. The list of organizations from which we interviewed experts is presented in Table 1. A shortcoming of the snowball method is that it can lead to an exclusion of groups that are not connected with the network that initiated the expert search. As it will be discussed later, an important group that was not intentionally excluded from the interviews was the media. We realized this only after we started to analyze the interviews. The reasons for exclusion of the media could be twofold: either our interviewees did not have contacts with the media or they did not consider them to be an important source of expert knowledge about adaptation. It could also have been a combination of both factors.

The interviews examined the experts' experience relating to adaptation, identifying innovative and the most promising adaptation options as well as barriers to and opportunities for their implementation. Each interview took about $1 \mathrm{~h}$ and was recorded and transcribed. In this paper, we focus primarily on the barriers to adaptation reported by the interviewees. The extracts of the interview text covering the above topics were coded and further analyzed using content analysis. This was carried out using software for qualitative data analysis (Nvivo). The software helps to manage unstructured information and provides tools for classifying, coding, sorting, and identifying themes and arranging information according to the needs of the study (Richards 1999).

\section{Empirical results}

\section{Different individual perceptions of adaptation}

Practically, all interviewed experts reported observed increased frequency and severity of extreme weather events and were very concerned about future impacts such as expected increasing damage costs and mortality rates. Some experts reported that they observe severity of extremes they have never before seen in their lives. Such statements were in particular made by the interviewees whose professional experience concerned adaptation to floods, droughts, and heat waves. There were also some reservations. Less observable was sea level rise. The interviewee from a company involved in building the Venice mobile gates that are being built to protect the Venice lagoon from flooding stated that: "I don't see sea level rise. I read about it, but I don't see it. It's not possible to see it for the time being, but we use the sea level rise in the design of the intervention." (Technital, Italy). The interviewees did not blame global warming for the increased frequency of climate extremes as such but more often attributed them to the way people have been managing land and other natural resources. In agriculture for instance, causes of weather-related stressors were attributed to overusing of water, removing buffer strips, deforestation, and merging fields into large land plots for the convenience of land cultivation, i.e., factors that made extremes of droughts and soil desertification more severe. A few interviewees also reported that flood protection measures and policies implemented in Europe in the twentieth Century actually resulted in escalating the extremes by the end of the Century. Building ever higher dams, regulating and narrowing rivers, as well as draining and occupying flood plains that happened in countries such as Hungary, Poland, and the Czech Republic in fact increased flood and damage risk according to the interviewees.

The interviewees reported and have been using various options in order to deal with the extremes and stated that many adaptation actions are already progressing. Nevertheless, the interviewees reported disagreements on such basic notions as weather extremes and adaptation itself. For example, a broker assistant from the KJF Insurance Broker 
Table 1 List of organizations represented by the interviewed experts

\begin{tabular}{|c|c|c|c|}
\hline Interview no. & Organization & Country & Focus of interviews \\
\hline 1 & Mission Risques Naturels; CEA Natural Hazards Working Group & France & Insurance sector \\
\hline 2 & Institute for Meteorology and Water Management & Poland & Floods, warning systems \\
\hline 3 & Polish Academy of Science Interviewee 1 & Poland & All extremes \\
\hline 4 & Polish Academy of Science Interviewee 2 & Poland & Agriculture, heat waves, drought \\
\hline 5 & Agricultural University of Poznan Interviewee 1 & Poland & Agriculture, heat waves, drought \\
\hline 6 & Agricultural University of Poznan Interviewee 2 & Poland & Agriculture, drought \\
\hline 7 & Potsdam Institute for Climate Impact Research (PIK) & Germany & Floods, droughts \\
\hline 8 & $\begin{array}{l}\text { Leibnitz Institute for Agricultural Engineering (ATB) } \\
\text { Potsdam Interviewee } 1\end{array}$ & Germany & Droughts in agriculture \\
\hline 9 & $\begin{array}{l}\text { Leibnitz Institute for Agricultural Engineering (ATB) } \\
\text { Potsdam Interviewee } 2\end{array}$ & Germany & Droughts and floods in agriculture \\
\hline 10 & $\begin{array}{l}\text { Leibnitz Institute for Agricultural Engineering (ATB) } \\
\text { Potsdam Interviewee } 3\end{array}$ & Germany & Adaptation in agriculture \\
\hline 11 & $\begin{array}{l}\text { Province Government, Department of Agricultural and } \\
\text { Rural Development }\end{array}$ & Poland & Adaptation in agriculture \\
\hline 12 & $\begin{array}{l}\text { VITUKI Environmental Protection and Water Management } \\
\text { Research Institute, Civil Engineer, Senior Research Associate }\end{array}$ & Hungary & Floods \\
\hline 13 & Farmer, Vice president of the National Grain Producer Federation & Poland & Adaptation in agriculture \\
\hline 14 & Ministry of the Environment, Hungary & Hungary & Floods \\
\hline 15 & Faculty of Economics, University of Coimbra & Portugal & Heat waves \\
\hline 16 & KJF Broker, Broker Assistant & Poland & Insurance \\
\hline 17 & Lowersilesian Eco-Development Foundation Eco-Union & Poland & Floods \\
\hline 18 & Institute for Structural Policy IREAS; Economic University, Prague & Czech Republic & Floods \\
\hline 19 & $\begin{array}{l}\text { Department of Agronomy and Land Management, } \\
\text { University of Florence }\end{array}$ & Italy & Heat waves \\
\hline 20 & Swedish Ministry of the Environment & Sweden & $\begin{array}{l}\text { Climate change impacts and } \\
\text { adaptation in the Scandinavian } \\
\text { countries }\end{array}$ \\
\hline 21 & $\begin{array}{l}\text { Farmer, Hungarian Association of Food Producers; } \\
\text { President of Scientific Association of Wine Producers }\end{array}$ & Hungary & Agriculture \\
\hline 22 & $\begin{array}{l}\text { World Wide Fund for Nature (WWF) Poland, Project Odra, } \\
\text { Project Manager }\end{array}$ & Poland & Floods \\
\hline 23 & World Wide Fund for Nature (WWF) Germany & Germany & WWF adaptation actions \\
\hline 24 & Swedish Environmental Protection Agency & Sweden & $\begin{array}{l}\text { Climate change impacts and } \\
\text { adaptation in the Scandinavian } \\
\text { countries }\end{array}$ \\
\hline 25 & Venice Water Authorities, member of the advisory board & Italy & Sea surge \\
\hline 26 & Technital, Italy & Italy & Sea level rise \\
\hline 27 & Balaton Uplands National Park Directorate & Hungary & Nature protection \\
\hline 28 & $\begin{array}{l}\text { National Institute of Environmental Health, Acting deputy } \\
\text { director general }\end{array}$ & Hungary & Heat waves \\
\hline 29 & Farmer & Hungary & Floods, droughts \\
\hline 30 & Mayor, local government, East-North Hungary & Hungary & Floods, droughts \\
\hline 31 & $\begin{array}{l}\text { Water Administration Board and Bodrog Basin } \\
\text { Landscape Protection }\end{array}$ & Hungary & Floods, droughts \\
\hline
\end{tabular}

said that the definition of drought differs between Polish law and insurance companies. These definitions differ again from farmers' understanding of droughts. Recognition of extremes such as droughts is further dependent on the measurement technology and location of the weather controlling stations that might report different weather conditions than those that occur on a specific farm. This leads to conflicts over insurance payments in case of losses. 
Different perceptions also existed in the understanding of adaptation and in the opinions on the effectiveness of various adaptation options. For example, an employee of the WWF Germany believed that the best adaptation strategy is mitigation of climate change. Others believed in adaptation as separate from mitigation action. Nevertheless, opinions on how to adapt differed enormously. An economist from the Potsdam Institute for Climate Impact Research claimed that spontaneous adaptation through financial instruments such as weather derivatives and insurance as well as free trade that responds to increasing prices of scarce resources will solve most climate change problems. Experts dealing particularly with transboundary river floods believed that a stronger coordination and government intervention in adaptation is necessary in order to avoid pushing the problem further away and to share adaptation costs due to unequally distributed impacts of extremes. Disagreements over the effectiveness of particular flood protection measures exist not only between different governments and between governmental and nongovernmental organizations but also between different state agencies. An employee of the Czech Institute for Structural Policy reported that in the Czech Republic, the water protection task is divided between the Ministry of Agriculture whose staff believe in building structural flood defense infrastructure, and the Ministry of Environment that believes in better performance of softer and more environment-friendly measures such as restoration of flood plains. The Ministries have a long history of conflict.

Table 2 presents characteristics of promising adaptation options to water extremes proposed by selected experts. ${ }^{2}$ Many of the characteristics are similar. For example, options are often cited as promising because they are in accordance with natural processes or they reduce risk and vulnerability. Some anomalies do arise however. For example, the argument of cost efficiency was brought up only by the interviewees from the Polish Academy of Sciences and the Swedish Ministry of the Environment. The President of the National Grain Producer Federation cited as promising, those options that employ traditional practices and are compatible with local property rights. The WWF Poland representative said that promising options are those that are not technical and are in accordance with social preferences. This contradicted the views of the employee of the Swedish Ministry of the Environment who thought that promising options use advanced technological structures.

\footnotetext{
$\overline{2}$ Only those experts are included who listed promising options to water extremes and justified their choice.
}

The array of mental models and institutional attributes

Beliefs as well as social and cultural values affect the choice of adaptation responses. Social acceptability of flood levels and certain adaptation options differ across countries. For example, in the Netherlands, people live with floods and a certain level of flooding is socially accepted even in urban areas. On the other hand, an interviewee from the WWF Poland reported that in Poland, there are embankments that are built to protect agricultural land and forest from floods. Also specific to Eastern Europe is the allocation of responsibility to the government with a demand that the government should take care of those affected by weather extremes and to help those for whom adaptation is too costly, e.g., farmers who cannot afford flood insurance. Reallocation that is frequent in China, in Europe usually faces strong local protests and is rarely used.

An employee of the Polish Institute for Meteorology and Water Management pointed out that constitutions of some countries guarantee their citizens a right to water, sometimes also free water access. For example in Poland, the state gives citizens a $100 \%$ water delivery guarantee. Together with low water prices in Poland, this leads to frequent wasting of water by both citizens and state administration and tensions during drought periods. Monitoring of water use is difficult since social norms often prohibit the denunciation of neighbors even if they waste water for watering lawns during droughts.

Adaptation is influenced by property rights systems. Certain adaptation options such as buffer strips in agriculture are not effective on small land plots. Similarly, as reported by an employee of the Swedish Ministry of the Environment, adaptation to storm wind in Swedish forestry is limited due to the relatively small size of forest plots. Here, adaptation requires coordination of forest owners in changing trees species and the way of placing new trees. Furthermore, a certain type of adaptation or lack of adaptation might be supported by economic interests of some groups in a society. As reported by the employee of the Institute for Structural Policy, there is a strong lobby of concrete producers that opts for constructing dams and other structural flood protection measures in the Czech Republic.

Groups of shared mental models

The results of the interviews showed that there are five basic actor groups involved in the policy process: advocacy groups, administration, politicians, researchers, and media and the public; each of these groups appeals to specific mental models, uses specific interpretations of climate change, and gives specific prescriptions for how to deal 
Table 2 Characteristics of promising adaptation options to water extremes cited by interviewees

\begin{tabular}{|c|c|c|}
\hline Interview no. & Interviewee & $\begin{array}{l}\text { Characteristics of promising adaptation options } \\
\text { (keeping the original order in listing the justifications) }\end{array}$ \\
\hline 3 & $\begin{array}{l}\text { Polish Academy of Science } \\
\text { (Poland) }\end{array}$ & $\begin{array}{l}\text { Supported by the EU policy } \\
\text { Raises awareness, providing information about risks } \\
\text { Reduces damage costs } \\
\text { Cost efficient } \\
\text { Quick to install } \\
\text { Easy to use } \\
\text { Accords with natural processes } \\
\text { Proactive } \\
\text { Supported by the government } \\
\text { Reduces risk } \\
\text { Well organized } \\
\text { Integrates information from various sources }\end{array}$ \\
\hline 13 & $\begin{array}{l}\text { Farmer, Vice president of } \\
\text { the National Grain } \\
\text { Producer Federation } \\
\text { (Poland) }\end{array}$ & $\begin{array}{l}\text { Employs traditional practices } \\
\text { Accords with natural processes } \\
\text { Taking into account the option's impacts in the future } \\
\text { Compatible with local property rights } \\
\text { Reducing weather extremes }\end{array}$ \\
\hline 20 & $\begin{array}{l}\text { Swedish Ministry of the } \\
\text { Environment (Sweden) }\end{array}$ & $\begin{array}{l}\text { Robust } \\
\text { Takes into account long-time perspective } \\
\text { Reduces risk } \\
\text { Reduces vulnerability } \\
\text { Supported by the EU policy } \\
\text { Provides economic benefits } \\
\text { Supports vulnerable species } \\
\text { Easy to use } \\
\text { Supported by national government } \\
\text { Cost efficient } \\
\text { Able to adjust to local conditions } \\
\text { Takes into account different future scenarios } \\
\text { Technical, adaptation through advanced physical conductions } \\
\text { Cross-sectoral } \\
\text { Integrates information from different sources, different knowledge } \\
\text { Easy accessible } \\
\text { Widely spread }\end{array}$ \\
\hline 22 & $\begin{array}{l}\text { WWF Poland, Project Odra, } \\
\text { Project Manager (Poland) }\end{array}$ & $\begin{array}{l}\text { Accords with natural processes } \\
\text { Serves people } \\
\text { Reduces vulnerability } \\
\text { Raises awareness } \\
\text { Has potential for wide implementation } \\
\text { Reduces damage costs } \\
\text { Non-technical, adaptation through changes in law, warning } \\
\text { systems, insurance, tax policy } \\
\text { Has minimal impact on the environment and natural processes } \\
\text { Takes into account the option's future impacts } \\
\text { Accords with social preferences }\end{array}$ \\
\hline
\end{tabular}


Table 2 continued

\begin{tabular}{lll}
\hline Interview no. & Interviewee & $\begin{array}{l}\text { Characteristics of promising adaptation options } \\
\text { (keeping the original order in listing the justifications) }\end{array}$ \\
\hline 26 & Technital (Italy) & $\begin{array}{l}\text { Flexible } \\
\text { Multidirectional (different solutions that help to achieve the final goal) } \\
\text { Has minimal impact on the environment } \\
\text { Robust and able to fulfill functions under different climate scenarios }\end{array}$ \\
& President of Water & $\begin{array}{l}\text { Provides opportunities for local communities } \\
\text { Administration Board and } \\
\text { Bodrog Basin Landscape } \\
\text { Protection (Hungary) }\end{array}$ \\
& $\begin{array}{l}\text { Reduces water extremes } \\
\text { Proactive } \\
\text { Efficient }\end{array}$ \\
\hline
\end{tabular}

with climate change impacts. The aims and logic of the groups are different which lead to significant obstacles in reaching a common understanding. Different groups back different arguments.

\section{Advocacy groups: demanding action or regulation}

Advocacy groups, such as businesses, farmers, and NGOs, are often seen as pursuing a normative point of view (e.g., "it is necessary to give space to rivers"), which can be based on and supported by facts (e.g., "ground water level has become lower in the last 20 years") and/or beliefs ("water is from God"). The advocacy can take various forms: from pure demand, based on assumptions that decision-makers (or any combination of administrations, politicians, or media) are ignorant, to more sophisticated methods of promotion of certain solutions and coalition building.

Business sector as an advocacy group The primary rationality attributed to the business sector is the following of economic incentives. The behavior of agents in this sector can be modified by the state or international regulations. For example, as a result of weak regulation of the insurance market, the interviewees reported that insurance companies were setting insurance too high, even creating barrier premiums. There were also problems with assessing damage costs. Due to the significant influence of regulations, the sector was perceived as being closely connected with the administration and lobbying politicians. The benefits the sector receives from status quo adaptation policies were also seen as a serious obstacle in implementation of some potentially promising adaptation options.

Farmers as an advocacy group Another advocacy group is comprised of farmers. In common with the business sector, they were seen as very sensitive to economic incentives. Subsidies and compensation of farmers in the case of locally negative external effects of certain adaptation options were seen as a factor important in modifying farmers' adaptation attitudes and behavior. The problem appears to be with the actions that require coordination. Certain adaptation options, e.g., buffer strips in agriculture, are not effective if they are implemented on small farms in isolation. Coordination is necessary since the result depends on the farmers' cooperative action. Such coordination can be achieved on a voluntary basis. However, particularly in Eastern Europe, lack of trust among farmers and negative experiences with socialistic cooperatives are seen as serious obstacles to cooperation on adaptation.

It was also noted that for farmers, tradition is very important. Sometimes, it is more important than economic incentives, or at least it makes them skeptical about changes which could potentially bring more profits. For instance, they believe that following their fathers' land cultivation practices and opposing technological innovations contributes to water inefficiencies and losses.

Environmentalists as an advocacy group Environmentalists and NGO representatives are seen as having too narrow a view of nature and being worried about "some green frogs". Members of other groups thought that nature is more robust than the environmentalist think. In addition, some of the interviewed political decision-makers were very critical of a lack of understanding by environmentalists of property rights and legal responsibilities. What seems to be simple for environmentalist, e.g., giving more space to water, is difficult to achieve for politicians and administrations. Allowing temporary flooding of private land, even if it is only farmland, imposes costs with no compensation on the owners, and farmers complain or even want to sue the regional administration for "improper" water management.

\section{Administration: focused on implementation and also having own interests}

Administration works on the implementation and delivery side. It is hierarchical and does not respond (at least 
directly) to demand coming from other groups. Administration was perceived by interviewees to be following procedures and the way things have been done there for years. In some units, people with certain backgrounds prevail e.g., engineering education. They do not acknowledge or simply do not want to be bothered with other approaches which for them are new. That is why they were perceived as very resistant to innovative options.

An interview with a representative of the WWF Poland observed that some state administration or public bodies are "states within the state". They do not take any suggestions from outsiders into consideration. There are also problematic cases where there are two state agencies with similar and not clearly separated competencies. This was observed in Venice between agencies appointed by the state water authorities and the local government and in the Czech Republic between the Ministry of Agriculture and the Ministry of the Environment. They developed two competing visions of extreme event management. As an interviewee from the Czech Institute for Structural Policy pointed out, "These institutions do not talk together much. They had huge fights in the past. Now they are slowly learning how to talk to each other. The money though still goes to people who use technical measures."

\section{Politicians: responsible for legislation}

Political decision-makers are seen as key actors since they are in charge of passing legislation which is a necessary component of many adaptation options. Politicians seek voters' support (the next election is the reference point). They can also be driven by beliefs, and they are highly dependent on the media. Politicians have more interest in structural adaptation options, since they are easier to "sell" to their electorate and their outcomes are more visible. They also believe that nature will find a way to deal with changes the new infrastructure brings. A problem, however, might occur if construction or implementation of another option takes a long time. Their election term is usually about 4 years. If realization of a project has a longer-time perspective than this, it can be difficult to find support for it. The politicians were seen by other interviewees as benefiting in various ways from certain publicly funded adaptation projects and thus blocking other competitive adaptation projects: "The mayor is afraid that financing the mobile gates will reduce financing for the city" (Technital, Italy).

Politicians themselves are usually very aware of property rights issues and legislation. They see financial instruments, subsidies, and compensation as very promising mechanisms. They also think that the private sector, e.g., insurance, could play a bigger role in risk management than currently and channel a higher proportion of the adaptation costs.
Another political group is that of local governments. Many interviewees felt that they can potentially play an important role in the adaptation process, particularly in coordination of and leadership among local actors. Through their close connection with local schools and teachers, they also have a chance to influence the local educational programs and change children's attitudes and behavior toward environmental problems. In addition, local governments are closely connected to many EU polices through various EU directives and funds. The EU policies, including adaptation-oriented policies, are perceived as more progressive and innovative than many state policies. Nevertheless, most of the time local governments were perceived as too small units to deal with the effects of climate change on their own. In an extreme case, they might continue to push responsibilities further or avoid responsibilities which might result in cumulating flood risk, e.g., downstream in the river basin. Such situations might also occur at the country level. As reported by the WWF Poland representative, the response of Germany after the floods on the Oder River at the beginning of the 2000s was to raise the dams on the German side of the river.

\section{Researchers: away from practice}

Researchers are often perceived as theoretically oriented and disconnected from reality. They are seen as unaware of ecological interdependencies and dynamics in real life, where various factors in time and space cannot be separated as is done in the laboratory or behind the desk. Moreover, they are often functioning only within one discipline and their recommendations highlight only one perspective.

The vice president of the Polish Association of Grain Producers reported that despite the fact that he is very successful in his farming business, his innovative adaptation practices in the production process are criticized by university professors as something that cannot work in Poland. But apparently, the innovative practices in question do work.

The interviewees pointed out that adaptation requires an interdisciplinary approach. "flood protection is not only about hydro-techniques (...). In this task all should participate, from a planning person to somebody who deals with finances. Of course hydro-technicians are also necessary, but it cannot be that it's a field just for one branch, because it has already been for years like that" (WWF Poland). At the same time, new approaches are needed to evaluate non-technical adaptation measures. As observed by an interviewee from the Czech Institute for Structural Policy, there are mathematical models to calculate performance of structural measures such as dams, but there are no models to evaluate performance and potential cost and 
benefits of measures such as "giving space to rivers". Thus, due to a lower assessment uncertainty, structural measures are preferred by decision-makers.

Interviewees from other sectors criticize the lack of consistency and strong variability of different research results. Variability of climate change impact models as well as different ways of measurement and looking at the data in complex systems results in disagreements between researchers and permit manipulation. For example, some effects are observable with a time delay, and there are different results in assessing sea level rise if we look at data for five, ten or 30 years.

The theories and impacts of climate change that researchers present change over time. This affects the business sector the most: "I am not an expert in sea level rise, I am an expert in how to deal with the sea level rise. Someone says it's $10 \mathrm{~cm}, 1 \mathrm{~m}, 2 \mathrm{~m}$, and I have to take into account these numbers, with a probability that it may happen. But the problem is that nobody talks about probabilities. There are just figures and they keep reducing these figures. In 1985 when they started mentioning sea level rise the first time, they were mentioning $1.5-2 \mathrm{~m}$. And then every 5 years they keep mentioning that the approach wasn't perfect and they keep reducing the expected sea level rise. Now we are dealing with approximately $50 \mathrm{~cm}$. I understand it's a very difficult task to understand what is going on. And you know scientists are mentioning numbers they keep studying in detail, but we have to use them, and our structures have to deal with the actual numbers, loads, forces. And if the level is not final, then it is a problem." (Technital, Italy).

\section{Public opinion and media: ignorant}

"The public" was seen by the interviewees as key in influencing politics. Politicians follow the interests of their voters. The public can make changes by fostering certain paths of policy or technology. However, the public is perceived as ignorant and not aware of the choices they make in their day-to-day life. A representative of the WWF Germany said: "People still do not realize what climate change means. What it means for us (...). We are changing the planet in a tremendous way. We cannot imagine what are we doing at the moment (...) there is still a big gap between talk and action. In mitigation and adaptation (...) we have no clue what's happening. They [the public] don't know really what it means. If they read it in the newspaper, I think they don't believe that (...) they have no idea what it really means, that there will be 3 billion people without water in the world (...). What are these people going to do, where will they stay? We are not prepared."

According to the interviewees, when a disaster happens the public attributes responsibility to the government. In many countries such as Hungary and Poland, there is currently no connection between who pays and who is protected by the measures. As a result, local inhabitants prefer protection measures such as dams, since they do not have to pay for them and they offer a feeling of higher protection. This can, however, sometimes be misleading. In addition, some risk management options such as controlled temporary flooding are not socially acceptable in these countries.

Members of other groups like researchers, environmentalists, or politicians believe the public can make changes by fostering certain paths of policy or technological development. Nonetheless, first they have to be aware of the choices they make in their day-to-day life.

Media was seen as the agent that can influence the public preferences in most of the countries not covering climate change problems adequately. An interviewee from the Swedish Environmental Agency pointed out that: "When we began this work 2 years ago we talked to agencies and they were not interested. Climate change is something for the far future; we don't have to deal with that. But with the media coverage that has been in Sweden for the last 1.5 years it's quite a different situation. The most important barrier is the thinking of people."

\section{Discussion and policy implications}

Adaptation can manifest itself in many forms. This also has been signaled by other authors (e.g., Aakre et al. in press; McEvoy et al. in press), who attributed the plurality of adaptation mainly to local variability of climate change impacts. In this article, we proposed that since a vast proportion of adaptation responses are implemented locally, adaptation will also depend on different individual perceptions of the environment and on different mental models societies and stakeholder groups use to solve problems they face. This proposition has been confirmed by empirical findings that show that the interviewed experts' mental representations of the environmental changes and prescriptions how to adapt vary across societal groups that have different experience and education. For example, the interviewed experts saw different factors as important in evaluating adaptation options. For some experts, cost efficiency was crucial in evaluating adaptation options, whereas other experts did not consider cost efficiency at all but took into account social preferences, for example. In order to deal with floods, administration and politicians tend to favor technical adaptation measures such as dams, channels, and embankments, since their performance can be calculated, and their outcomes are visible. In contrast, representatives of environmental organizations tend to favor non-technical measures such as insurance and 
the raising of awareness since their impact on the environment and natural processes is believed to be lower. Such specific visions of the environment are supported furthermore by institutions such as rules of distribution of public funds, land use regulations, and insurance or disaster relief programs.

Our findings are important for participatory processes, including scenario building and modeling. Results of participatory processes might vary widely according to which stakeholder groups are included. Since mental models are dynamic and changeable, results of stakeholder workshops can also vary across time. Even if we repeat the same workshop with the same participants, over time due to learning and readjustment of mental models, visions and preferences expressed by the workshop participants can change. Our findings emphasize the importance of interdisciplinary and transdisciplinary research. Approaching environmental problems by including different disciplines and perspectives of different sectors gives a higher chance of identifying potential errors and gaps in models and theories constructed by scientists. Such approach is intuitively supported by the EU policy. The research framework programs give preferences to projects including interdisciplinary research and integrating a wide range of both policy and praxis oriented partners. The generated communication and cooperation can exhibit social learning processes and result in a mutual readjustment and enhancement of each other's mental models. Such good practices could be replicated by adaptation policies.

Political decision-makers should pay attention to the provision of conditions and legal frameworks which enable communication, information, feedback, and responses between various state and non-state actors. Legal frameworks could play an important role in unifying definitions and procedures that are used in generating responses to climate-related disasters and in assessing damage costs. This is particularly important for financial mechanisms such as insurance and weather derivatives that create new, vastly unregulated, markets. Consumers also have to understand the mechanisms and opportunities they generate. As our interviewees pointed out, lack of information and lack of regulation can be used for the benefit of powerful actors. Thus, actions related to education and raising of awareness are of a particular importance. This role could be played by media. The interviewed experts recognized that the media could play an important role in adaptation. However, at the time the interviews were carried out, the media was seen as ignorant and not covering topics related to climate change and adaptation adequately. The exclusion of media representatives from the interviews that followed the "snowball" interviewee selection method demonstrates weak connections between media and the interviewed adaptation experts.
In the end, the plurality of adaptation responses creates a large experimental field where various adaptation options and new governance structures such as public-private partnerships are tried and tested. Monitoring and learning from successes and failures in adaptation responses could improve feedback transparency and a verification of mental models in use.

\section{Conclusions}

The article presents analysis of 31 in-depth interviews with European experts on adaptation to climate change. We investigate how different groups of stakeholders perceive and deal with adaptation and climate change impacts. We show that mental models representing visions of how to adapt and how to govern adaptation strongly differ. Uncertainty related to climate change impacts and measurement of performance of various adaptation measures as well as feedback delays hinder verification of the mental models. The analysis also shows how lack of information and understanding of the environmental complexities can be abused by interest groups.

In addition, each group of actors perceives the other groups as ignorant with respect to each others' knowledge and recommendations. This is particularly challenging since adaptation often requires coordination across scales and sectors. Coordination and cooperation is hard to achieve if the involved actors perceive each other as ignorant and are not open to each others' arguments.

Learning and exchange might be facilitated by participatory approaches and early involvement of stakeholder groups in the policy process. In a participatory process, it is more likely that the stakeholders develop a shared understanding of concept and language used by each other. Climate change impacts are and will vary according to location. The performance of adaption intervention might also be affected by location specific social and economic systems, such as property rights structures and specific norms and institutions. Thus, it is difficult to talk in terms of the best adaptation option or the most promising. Things that work in one place might not work in another. As it was recommended by one of our interviewees, delegating most of adaptation responsibilities to lower government levels such as a county could facilitate adaptation more tailored to the specific local conditions and needs.

Acknowledgments The authors acknowledge comments on the article given by Jill Jäger, Dimitrios Zikos, and anonymous referees. The research also benefited from presenting and discussing it at the Ronald Coase Institute Workshop on Institutional Analysis that took place in Bratislava in May 2009. The authors would like to acknowledge funding acquired from the following sources: Adaptation and Mitigation Strategies Supporting European Climate Policy 
(ADAM) Project, Multi-level Governance of Natural Resources: Tools and Processes for Water and Biodiversity in Europe (GoverNat) Project, and Wageningen Institute for Environment and Climate Research (WIMEK).

Open Access This article is distributed under the terms of the Creative Commons Attribution Noncommercial License which permits any noncommercial use, distribution, and reproduction in any medium, provided the original author(s) and source are credited.

\section{References}

Aakre S, Banaszak I, Kalirai H, Mechler R, Rübbelke D, Wreford A (2010) Adaptation to disaster risk in the EU: improving the role of the public sector. Mitig Adapt Strateg Glob Change (in press)

Besnard D, Greathead D, Baxter G (2004) When mental models go wrong: co-occurrences in dynamic, critical systems. Int J Hum Comput Stud 60:117-128

Cannon-Bowers JA, Salas E, Converse S (1993) Shared mental models in expert team decision making. In: Castellan NJ Jr (ed) Individual and group decision making. Current issues. Lawrence Erlbaum, Hillsdale

Denzau AT, North DC (1994) Shared mental models: ideologies and institutions. Kyklos 47(1):3-31

EEA (2007) Europe's environment. The fourth assessment. European Environment Agency, Copenhagen

Feijoo C, Momo F (1991) Socio-economic levels and environmental perception in a small town in Argentina. The Environmentalist 11(3): $163-170$

Filip J, Funtes E, Donso S, Martini S (1983) Environmental perception of mountain ecosystems in central Chile: an exploratory study. Hum Ecol 11(3):351-354

Forrester JW (1971) Counterintuitive behavior of social systems. Theory Decis 2:109-140

Forrester JW (1991) System dynamics and the lessons of 35 years. In: De Greene KB (ed) The systemic basis of policy making in the 1990s. MIT Press, Cambridge

Irwin A (1995) Citizen science. Routledge, London

Jennings TJ (2009) Exploring the invisibility of local knowledge in decision making: the Boscastle Harbour Flood Disaster. In: Adger WN, Lorenzoni I, O'Brien K (eds) Adapting to climate change: thresholds, values, governance. Cambridge University Press, Cambridge

Klein RJT, Huq S, Denton F, Downing TE, Richels RG, Robinson JB, Toth FL (2007) Interrelationships between adaptation and mitigation climate change 2007: impacts, adaptation and vulnerability. In: Parry ML, Canziani OF, Palutikof JP, van der Linden PJ, Hanson CE (eds) Contribution of working group II to the fourth assessment report of the intergovernmental panel on climate change. Cambridge University Press, Cambridge

Lorenzoni I, Pidgeon NF (2006) Public views on climate change: European and USA perspectives. Clim Change 77(1-2):73-95

McEvoy D, Lindley S, Handley J (2006) Adaptation and mitigation in urban areas: synergies and conflicts. Proc Inst Civil Eng Munic Eng 15(4):185-191

McEvoy D, Matczak P, Banaszak I, Choryński A (2010) Framing adaptation to climate-related extreme events. Mitig Adapt Strateg Glob Change (in press)
Mechler R, Hochrainer S, Aaheim A, Kundzewicz Z, Lugieri N, Moriondo $\mathrm{M}$ et al (2010) A risk management approach for assessing adaptation to changing flood and drought risk in Europe. Mitig Adapt Strateg Glob Change (in press)

Meuser M, Nagel U (1991) Expertinneninterviews; vielfach erprobt, wenig bedacht. Ein Beitrag zur qualitativen Methodendiskussion. In: Garz D, Kraimer K (eds) Qualitativ-empirische, Sozialforschung, Konzepte, Methoden, Analysen. Westdeutscher Verlag, Opladen

North DC (1990) Institutions, institutional change and economic performance. The Press Syndicate of the University of Cambridge, Cambridge

O'Brien K (2009) Do values subjectively define the limits to climate change adaptation? In: Adger WN, Lorenzoni I, O’Brien K (eds) Adapting to climate change: thresholds, values, governance. Cambridge University Press, Cambridge

Pahl-Wostl C, Hare M (2004) Process of social learning in integrated resource management. J Commun Appl Soc Psychol 14:193-206

Papadozomenou R, Zikos D (2009) Linking perceptions and water management: reflections from Cyprus. Trans Environ Dev 12(5):749-758

Richards L (1999) Using NVivo in qualitative research. Sage, London

Rouse WB, Morris NM (1986) On looking into the black box: prospects and limits in the search for mental models. Psychol Bull 100(3):349-363

Schoell R, Binder CR (2009) System perspectives of experts and farmers regarding the role of livelihood assets in risk perception: results from the structured mental models approach. Risk Anal 29(2):205-222

Schulser TM, Decker DJ, Pfeffer MJ (2003) Social learning for collaborative natural resource management. Soc Nat Resour 15:309-326

Senge P (1990) The fifth discipline: the art and practice of the learning organization. Doubleday, New York

Sterman JD (2008) Risk communication on climate: mental models and mass balance. Science 332(5901):532-533

Sudarmadi S, Suzuki S, Kawada T, Netti H, Soemantri S, Tritugaswa A (2001) A survey of perception, knowledge, awareness, and attitude in regard to environmental problems in a sample of two different social groups in Jakarta, Indonesia. Environ Dev Sustain 3(3):169-183

Tàbara JD, Ilhan A (2008) Culture as trigger for sustainability transition in the water domain: the case of the Spanish water policy and the Ebro river basin. Reg Environ Change 8(2):59-71

Taenzler D, Carius A, Maas A (2008) Assessing the susceptibility of societies to droughts: a political science perspective. Reg Environ Change 8(4):161-172

Vari A, Linnerooth-Bayer J, Ferencz Z (2003) Stakeholder views on flood risk management in Hungary's Upper Tisza basin. Risk Anal 23(3):585-600

Vatn A (2005) Institutions and the environment. Edward Elgar, Cheltenham

Wolf J, Lorenzoni I, Few R, Abrahamson V, Raine R (2009) Conceptual and practical barriers to adaptation: vulnerability and responses to heat waves in the UK. In: Adger WN, Lorenzoni I, O'Brien K (eds) Adapting to climate change: thresholds, values, governance. Cambridge University Press, Cambridge 